\title{
A sustainable urban development and crises management: Empirical investigation on redesigning Tehran Arg square
}

\author{
Mohammad Rahim Rahnama ${ }^{a}$ and Hana Yazdanfar ${ }^{b^{*}}$
}

${ }^{a}$ Associate Professor, Department of Geography, Ferdowsi University of Mashhad, Mashhad, Iran ${ }^{b}$ PhD Student in Geography \& Urban Planning, Ferdowsi University of Mashhad, International Campus, Mashhad, Iran CHRONICLE ABSTRACT

Article history:

Received June 28, 2013

Received in revised format 19 October 2013

Accepted 23 October 2013

Available online

December 62013

Keywords:

Sustainable development

Principles of sustainable urban

Crisis management

\begin{abstract}
A B S T R A C T
This paper presents an empirical investigation on redesigning Tehran Arg square based on principles of sustainable urban development and crises management. The proposed study performs the study based on three perspectives including quality improvement, sustainability and crisis management. In terms of city quality improvement, the study detects six factors including social interaction, cleanliness, attractiveness, comfort, vitality and security. In terms of sustainability, the study discusses three areas including different types of construction, high density and use of clean energy in buildings. Finally, in terms of crisis management, the study discusses five perspectives including wide open spaces, appropriate coverage of the floor space, appropriate performance, strength of neighboring buildings and suitable materials.
\end{abstract}

\section{Introduction}

One of the most important issues in city development is to take care of historical complex because they are part of country's heritage (Burton et al., 2004; Jenks, 2000; Aguilar et al, 2003). In Iran, there are various historical monuments and Arg square has been recorded as ten thousandth registered historical monuments in the country. Arg square is about 900 meters from north to south and about 500 meters from West to East is an area of approximately 45 hectares encompassing. The first academy of science and the first public museum were established in this area and many political events were held in this region in the past. This region is located in an old part of Tehran city and there are several studies on development of the city based on sustainable city development as well as crisis management. The issue is not limited to this city and similar studies have been accomplished in the past in other parts of the world.

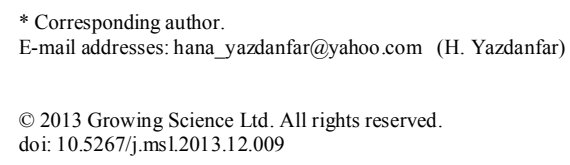


Dimitrova (2014) discussed the effect of context, both geopolitical Central and Eastern Europe (CEE), and professional-urban and regional planning, on the educational concept and the choices established on the modules' structure, contents and result evaluation based on a ten-year experience of embedding the 'sustainable development' topic into a newly built program in Urbanism in Sofia. Through analyzing detected contextually rooted challenges and success factors in the educational process, and their association with the broader global and regional process, the study explained the necessity for a better concentrated and contextually sensitive support to the local endeavors for integrating the SD topic into the restructuring higher education institutions in the CEE region.

According to Nevens et al. (2013), a transition management approach in different cities could result in a cycle of five distinct phases including problem structuring and envisioning, process design and system analysis, back casting, detecting major pathways and agenda setting, analyzing and monitoring and evaluation.

Abdel-Galil (2012) provided an urban sustainable management system (USMS) for new developments on desert reclaimed land in Egypt. The USMS contributed to the paradigm of sustainable urban management in three perspectives. First, it has provided a consistent set of indicators, prioritized based on settlers' requirements and local problems. Second, it analyzed data unavailability by applying comparable national, international and local information. Finally, the USMS not only measured, it provided an evaluative framework, applied it and engaged with questions of sustainable levels and values.

Woolthuis et al. (2013) studied three cases of sustainable urban development in Germany and explained that sustainable urban development is a wicked problem. Higgins (2013) discussed various factors associated with sustainable development including carbon control and investigated different perspectives of urban transformation in Hong Kong and London. Rehan et al. (2014) presented financially sustainable management strategies for urban wastewater collection infrastructure. Rehan et al. (2013), in other work, developed a system dynamics model for financially sustainable management of municipal watermain networks. The urban development can also be influenced by financial crisis (Canova et al., 2012; Colding et al., 2013).

\section{The proposed study}

This paper presents an empirical investigation on redesigning Tehran Arg square based on principles of sustainable urban development and crises management. The proposed study performs the study based on three perspectives including quality improvement, sustainability and crisis management.

\subsection{Quality improvement}

Quality improvement can be considered in four different perspectives including access and linkage, comfort and image, uses and activities and sociability. The proposed study of this paper has extended the concept of quality in terms of ten different factors including cleanliness, accessibility, attractiveness, comfort, comprehensive, vitality, performance, distinctive and health care.

\subsection{Sustainability}

Sustainability is another important issue in urban city development and in order to have a sustainable plan we need to consider various factors including human's capabilities, giving more value to ecosystem, having friendly relationship with environment, partnership, having systematic insight, being flexible, etc.

\subsection{Crisis management}

The third issue on having urban city development is to manage possible crisis, very carefully. In fact, the Arg city suffers from weak infrastructure and any redesign development has to improve basic 
requirements such as firefighting equipment, emergency exits, etc. Therefore, we may consider various factors such as wide open spaces, appropriate coverage of the floor space, appropriate performance, strength of neighboring buildings and suitable materials.

\section{Case study}

Arg square is about 900 meters from north to south and about 500 meters from West to East is an area of approximately 45 hectares encompassing. Fig. 1 shows the position of Arg square in Tehran city.

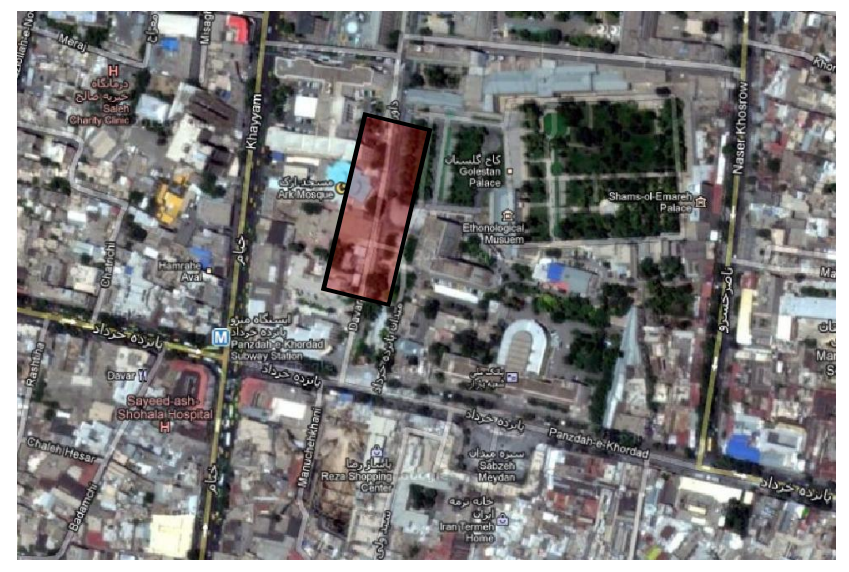

Fig. 1. Arg Square

In this study, we have investigated development of the city in terms of three perspectives including quality improvement, sustainability and crisis management.

\subsection{Quality improvement}

In terms of city quality improvement, the study detects six factors including social interaction, cleanliness, attractiveness, comfort, vitality and security. In terms of social interaction, we need to establish various cultural ceremonies in this region. Cleanliness is another perspective of this study and for urban development and we need to install some trashes to recycle garbage, very carefully. For redesign perspective of this square, we need to consider various traditional features to change the environment. The city management has to consider possible bench to furnish the city.

\subsection{Sustainability}

In terms of sustainability, the study discusses three areas including different types of construction, high density and use of clean energy in buildings. The region has to have various building for different purposes such that all people in society could take advantage.

\subsection{Crisis management}

Finally, in terms of crisis management, the study discusses five perspectives including wide open spaces, appropriate coverage of the floor space, appropriate performance, strength of neighboring buildings and suitable materials. The region must be furnished with suitable tiles so that the region has a unique and attractive landscape and people could walk very easily.

\section{Conclusion}

In this paper, we have briefly discussed various issues associated with urban development in the world and explained how we could improve the quality of a historical monument in Tehran city, Iran by carefully considering various factors such quality improvement, sustainability and crisis 
management. In terms of city quality improvement, the study has detected six factors including social interaction, cleanliness, attractiveness, comfort, vitality and security. In terms of sustainability, the study has suggested three areas including different types of construction, high density and use of clean energy in buildings. Finally, in terms of crisis management, the study discusses five perspectives including wide open spaces, appropriate coverage of the floor space, appropriate performance, strength of neighboring buildings and suitable materials.

\section{References}

Abdel-Galil, R.E.S. (2012). Desert reclamation, a management system for sustainable urban expansion. Progress in Planning, 78(4), 151-206.

Aguilar, A. G., Ward, P. M., \& Smith Sr, C. B. (2003). Globalization, regional development, and mega-city expansion in Latin America: analyzing Mexico City's peri-urban hinterland. Cities, 20(1), 3-21.

Burton, E., Jenks, M., \& Williams, K. (Eds.). (2004). The compact city: a sustainable urban form?. Routledge.

Canova, N.P., \& Hickey, G.M. (2012). Understanding the impacts of the 2007-08 global financial crisis on sustainable forest management in the Brazilian Amazon: A case study. Ecological Economics, 83, 19-31.

Colding, J., Barthel, S., Bendt, P., Snep, R., van der Knaap, W., \& Ernstson, H. (2013). Urban green commons: Insights on urban common property systems. Global Environmental Change, 23(5), 1039-1051.

Dimitrova, E. (2014). The 'sustainable development' concept in urban planning education: lessons learned on a Bulgarian path. Journal of Cleaner Production, 62(1), 120-127.

Higgins, P. (2013). From sustainable development to carbon control: urban transformation in Hong Kong and London. Journal of Cleaner Production, 50(1), 56-67.

Jenks, M. (2000). Compact cities: sustainable urban forms for developing countries. R. Burgess (Ed.). Taylor \& Francis.

Nevens, F., Frantzeskaki, N., Gorissen, L., \& Loorbach, D. (2013). Urban Transition Labs: cocreating transformative action for sustainable cities. Journal of Cleaner Production, 50(1), 111122.

Rehan, R., Knight, M.A., Unger, A.J.A., \& Haas, C.T. (2013). Development of a system dynamics model for financially sustainable management of municipal watermain networks. Water Research, 47(20), 7184-7205

Rehan, R., Knight, M.A., Unger, A.J.A., \& Haas, C.T. (2014). Financially sustainable management strategies for urban wastewater collection infrastructure - development of a system dynamics model. Tunnelling and Underground Space Technology, 39, 116-129

Woolthuis, R.K., Hooimeijer, F., Bossink, B., Mulder, G., \& Brouwer, J. (2013). Institutional entrepreneurship in sustainable urban development: Dutch successes as inspiration for transformation. Journal of Cleaner Production, 50(1), 91-100 